\title{
Endoscopic management of difficult common bile duct stones
}

\author{
L.A. Lesmana
}

\begin{abstract}
Abstrak
Telah diselidiki 45 pasien dengan batu saluran empedu (BSE) sulit yang tidak dapat dikeluarkan dengan kombinasi sfingterotomi endoskopik dan pengeluaran batu menggunakan basket Dormia. Ke-45 pasien ini menjalani prosedur endoskopik tambahan; litotripsi mekanik (LM) pada 22 (49\%), litotripsi elektrohidrolik (LEH) atau litotripsi laser (LL) melalui koledokoskopi peroral pada 7 (15\%), dan pemasangan endoprostesis bilier pada 16 pasien lainnya (36\%). Kelompok terakhir ini terdiri dari pasien lanjut usia dengan umur rerata 79 tahun (kisaran 72-85) yang disertai kolangitis dan risiko operasi. Pembersihan saluran empedu didapatkan pada seluruh 22 pasien yang menjalani LM. Pemecahan dan pengeluaran batu diperoleh pada 7 pasien dengan LEH atau LL. Pada satu pasien, batu timbul kembali dua tahun sesudah LEH dan memerlukan tindakan operasi. Keberhasilan drainase empedu didapatkan pada 16 pasien dengan endoprostesis. Lima pasien mengalami penyumbatan endoprostesis selama pemantauan 24 bulan; tiga berhasil menjalani LM dan dua lainnya mendapatkan endoprostesis baru. Tidak ditemukan komplikasi dalam studi ini. Prosedur endoskopik tambahan bermanfaat dalam tatalaksana BSE sulit.
\end{abstract}

\begin{abstract}
We have studied 45 patients with difficult common bile duct (CBD) stones which could not be removed with endoscopic sphincterotomy combined with stone removal using a Dormia basket. These 45 patients underwent additional endoscopic procedures: mechanical lithotripsy $(M L)$ in $22(49 \%)$, electrohydraulic (EHL) or pulse dye laser lithotripsy via peroral choledochoscopy in 7 (15\%), and biliary stenting in the remaining $16(36 \%)$. The latter group consisted of elderly patients with an average age of 79 years (range 72-85) who had cholangitis and surgical risk. Duct clearance was achieved in all 22 patients undergoing ML. Fragmentation and stone extraction were successful in all 7 patients with EHL or laser lithotripsy. One patient developed recurrent stone two years later after EHL which required surgery. Resolution of cholangitis and cholestasis indicating successful bile drainage was achieved in all 16 stented patients. However, 5 patients developed stent-clogging during 24 month follow-up; three of these subsequently underwent successful $M L$ and the other two received new-stent. No complications were noted in this study. Additional endoscopic procedures are beneficial in treating difficult $C B D$ stones.
\end{abstract}

Keywords: biliary stenting, lithotripsy, endoprosthesis, choledochoscopy

Endoscopic management of common bile duct (CBD) stones has become the treatment of choice, especially after cholecystectomy and in patients with high surgical risk since the introduction of endoscopic sphinchterotomy (ES) in 1974. ${ }^{1,2}$ A number of studies have reported that $80-90 \%$ of $\mathrm{CBD}$ stones can be successfully removed by endoscopic sphincterotomy followed with stone removal using a Dormia basket or a balloon catheter. ${ }^{3-5}$ However, in patients with difficult CBD stones which include large stones, impacted stones, or stones located above the ductal narrowing, several additional techniques have been developed for endoscopic removal of the stones through the incised papilla.

Department of Internal Medicine, Faculty of Medicine, University of Indonesia, Jakarta, Indonesia
Fragmentation of stones prior to removal can be accomplished by mechanical lithotripsy, ${ }^{6-8}$ electrohydraulic shock wave lithotripsy, ${ }^{8-10}$ extracorporeal shock wave lithotripsy, ${ }^{11,12}$ and laser lithotripsy. ${ }^{13,14}$ If all these attempts fail to extract or crush large CBD stones and the patient has a high surgical risk, then insertion of an endoscopic biliary-prosthesis along the impacting concrements has been suggested. ${ }^{15-17}$

We report herein our experience with additional endoscopic procedures in patients with difficult CBD stones.

\section{METHODS}

During a five year period (1990-1994), 266 patients were diagnosed to have CBD stone(s) at endoscopic retrograde cholangiography (ERC) at the Hepato- 
biliary unit, Husada hospital, Jakarta. All patients underwent endoscopic sphincterotomy (ES) and attempted removal of the stones using a Dormia basket with a diameter of $22 \mathrm{~mm}$ and length of $40 \mathrm{~mm}$ (FG 22 Q, Olympus optical Co., Tokyo, Japan).

Successful ES and stone extraction were obtained in $262(98 \%)$ and $197(74 \%)$ patients respectively. Of the 65 patients with Dormia extraction failure, 20 underwent surgery prior to the availability of lithotryptor and biliary stent at our unit. The remaining 45 patients were defined to have difficult CBD stones (large, impacted, or stones located above the distal narrowing) and included in this study.

There were 26 females and 19 males with a mean age of 62 years (range 34-85 years). Patients with difficult CBD stones underwent mechanical, electrohydraulic or pulse dye laser lithotrypsy and biliary stenting according to the following algorithm: a) mechanical lithotripsy for stones which could not be removed after grasping in the Dormia basket, b) electrohydraulic or pulse dye lithotripsy for stones which could not be engaged in the Dormia basket (impacted stones), or c) biliary stenting for patients who had cholangitis and surgical risk.

\section{Additional endoscopic procedures}

\section{Mechanical lithotripsy}

Mechanical lithotripsy (ML) was performed either with Soehendra lithotryptor (Wilson-Cook Medical Inc., Winston Salem, North Carolina, USA) or BML lithotryptor (Olympus Optical Co., Tokyo, Japan).

The Soehendra lithotryptor consists of a cranking device and a $6 \mathrm{~mm}$ metal coil sheath. First, the handle of the Dormia basket containing the entrapped stone was clipped off and the endoscope was removed from the patient. A metal coil sheath was then advanced over the plastic catheter up to the basket under fluoroscopic guidance. The basket wire and the sheath were then connected to the cranking device and the stone was crushed by drawing the basket forcefully into the metal sheath.

The Olympus BML lithotryptor consists of coil sheath, tube sheath, basket wire, and BML handle. First, the instrument was introduced into the bile duct through the incised papilla. The basket was opened by pushing the holder of BML and the stone was then captured. After grasping the stone, the knob of the BML handle was rotated to crush the stone by squeezing with the basket.

\section{Electrohydraulic and pulse dye laser lithotripsy}

Electrohydraulic or pulse dye laser lithotripsy were carried out via peroral choledochoscopy using the "mother-baby" endoscope system (Olympus TJF M20 mother scope and Olympus CHF B20 babyscope).

Electrohydraulic lithotripsy. Prior to performing EHL, a 7FR nasobiliary catheter was inserted above the stone for bile duct irrigation with physiological saline to provide a fluid medium for effective generation and conduction of EHL shock wave and to allow control cholangiography. After positioning the motherscope in front of the incised papilla, the babyscope was passed through the operating channel of the motherscope and introduced under direct vision into the common bile duct. The bile duct was examined endoscopically and impacted stone was localized. A 4.5 FR EHL probe, connected to the shock wave generator unit (Lithotron EL 23, Walz Electronic Inc., Germany), was inserted through the operating channel of the babyscope and placed directy to the stone surface. The shock wave generator was set to discharge twelve impulses per second in volleys of 3 impulses; the energy was set at 0.46 Joule per impulse. Using a foot pedal to activate the generator, spark discharges were applied over one to two seconds. This was repeated until all stone fragments were passable through the incised papilla. Duct clearance was confirmed by cholangiography.

Pulse dye laser lithotripsy. The flashlamp pulsed dye laser (Pulsolith, Technomed International, Lyon, France) was used in this study. The dye was Coumarin green, producing a laser pulse wave length at $504 \mathrm{~nm}$ with a pulse duration of 2.4 microseconds.

The laser beam was transmitted to the impacted stone by direct contact via a 3-m long, $200 \mu \mathrm{m}$ diameter flexible quarts fiber inserted into the common bile duct through the operating channel of the babyscope. The procedure was repeated until fragments of stones could be removed through the incised papilla.

\section{Biliary stenting}

A straight 7 or $10 \mathrm{FR}$ endoprosthesis with side flaps (Wilson Cook Medical Inc., Winston-Salem, North Carolina, USA) were inserted into the common bile duct so that the proximal end was positioned above the 
stone(s) and, when possible, wedged in the intra hepatic ducts to prevent dislodgement. The distal end of the endoprosthesis was placed in the duodenum.

\section{RESULTS}

The outcome of endoscopic management of 45 patients with difficult CBD stones is summarized in Figure 1.

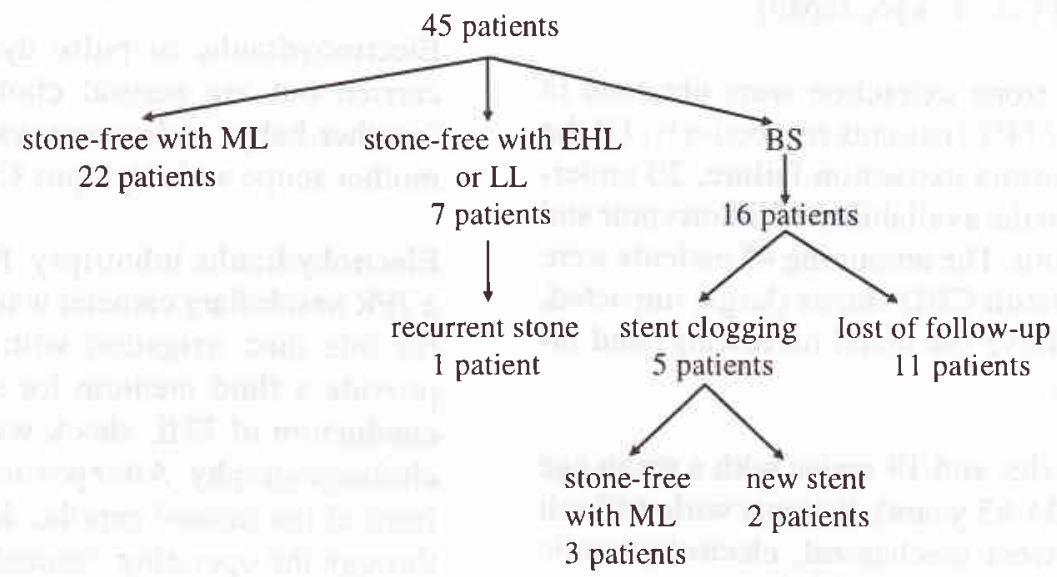

Figure.1. Outcome of difficult $C B D$ stones using mechanical lithotripsy $(M L)$, electrohydraulic lithotrophy (EHL), pulse dye laser lithotripsy (LL) and biliary stenting (BS).

ML was performed in $22(49 \%)$ patients, 9 with Soehendra lithotryptor and the other 13 with Olympus BML lithotryptor. In all of these 22 patients, ML could successfully fragment large stones or stones located above the ductal narrowing in one session (Figure 2 and 3). The majority of the stones were macroscopically pigment type. In patients with several big stones, BML lithotryptor was preferably used since the procedure could be repeated several times without the necessity to remove the endoscope from the patient. No complications were found with both of the techniques.
Seven (15\%) patients with impacted stones were submitted to electrohydraulic or pulse dye laser lithotripsy under cholangioscopic guidance. There was no spesific reason in selecting EHL or LL. This approach required two endoscopists during fragmentation of the stones; one would handle the motherscope and simultaneously direct the babyscope while the other fragmented the stones with electrohydraulic shock wave or laser beam. Fragmentation of the stones and duct clearance were achieved in all 7 patients in one session: five with EHL and two with LL (Figure 4). One patient with markedly
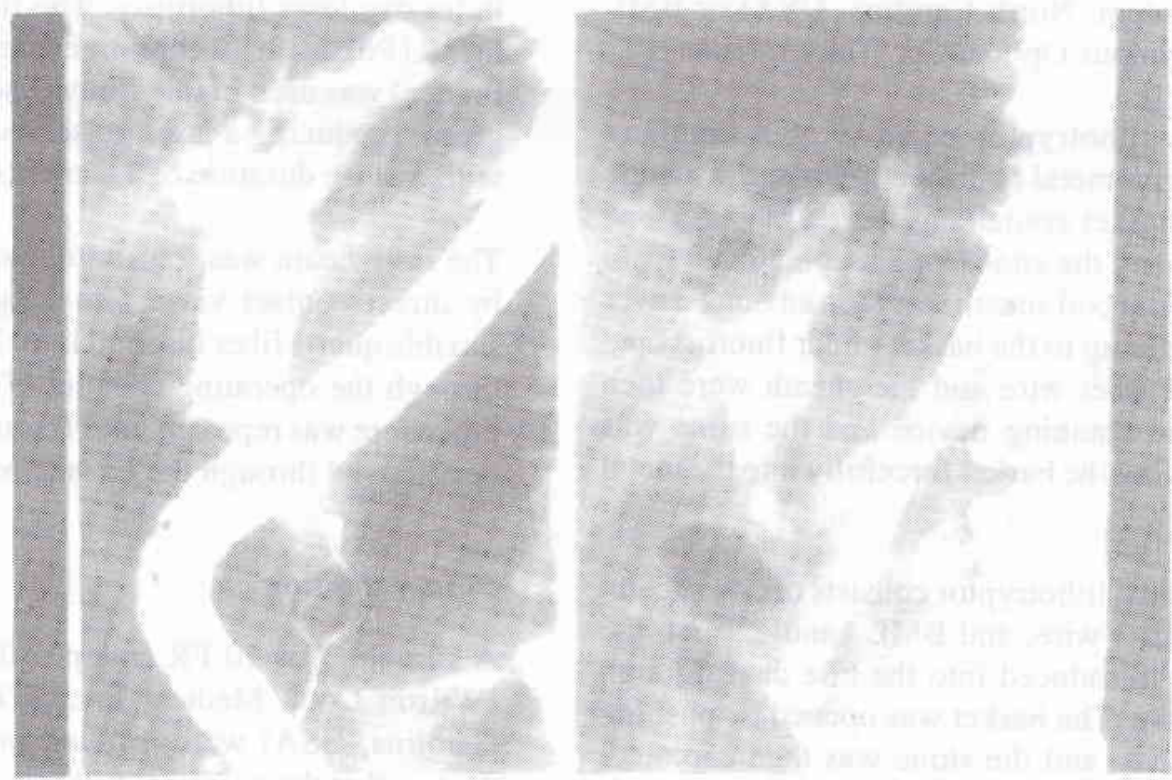

Figure 2. Mechanical lithotripsy of a large $C B D$ stones using oehendra lithotriptor 


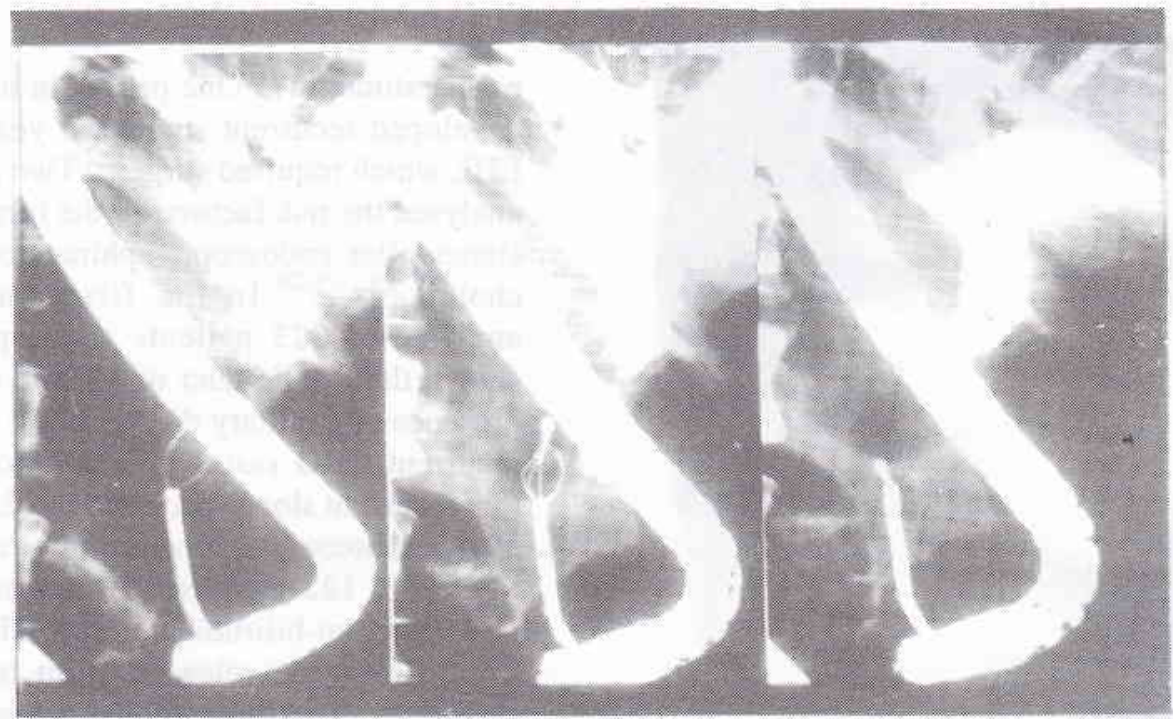

Figure 3. Mechanical lithotripsy of a $C B D$ stone with ductal narrowing using Olympus BML lithotriptor

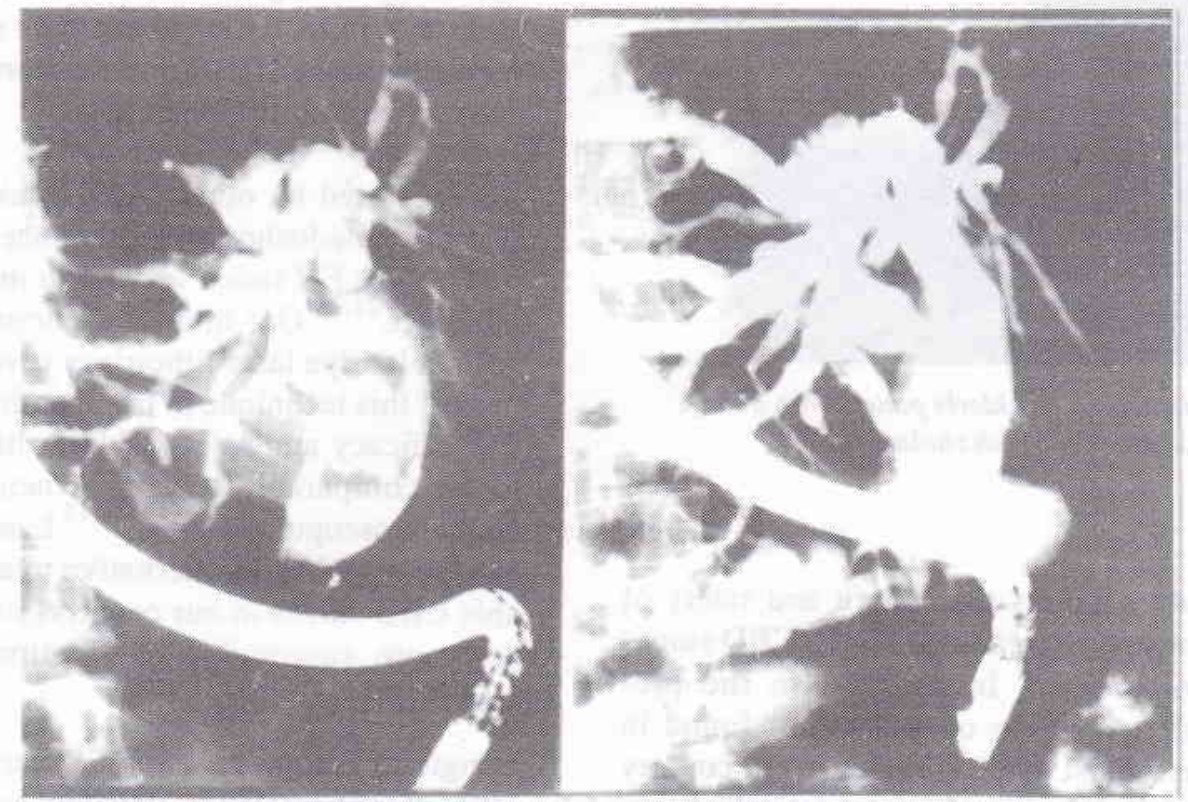

Figure 4. A large impacted $C B D$ stone on the left and a clear bile duct on the right after electrohydraulic lithotripsy

dilated CBD developed recurrent stone two years after EHL. This patient underwent successful surgical exploration of the CBD, and the stone was brown and soft being characteristically of calcium bilirubinate type.

Minor bleeding occurred in two patients when the electrohydraulic shock waves contacted the bile duct wall. The bleeding stopped spontaneously in both of the patients. No other complications were found.

The remaining 16 elderly patients with an average age of 79 years (range 72-85) presented with cholangitis, defined as the combination of fever, leucocytosis and stones in the biliary tract. Successful biliary drainage, defined as resolution of jaundice and fever, was achieved in all 16 patients (100\%) after placement of an endoprosthesis in the CBD (Figure 5).

During 24 month follow-up, five patients developed clogging of the stent; three of these subsequently underwent successful ML and the other two patients received new stents. Longterm complications of the remaining 11 patients could not be monitored due to lost of contact. There were no complications related to this procedure. 


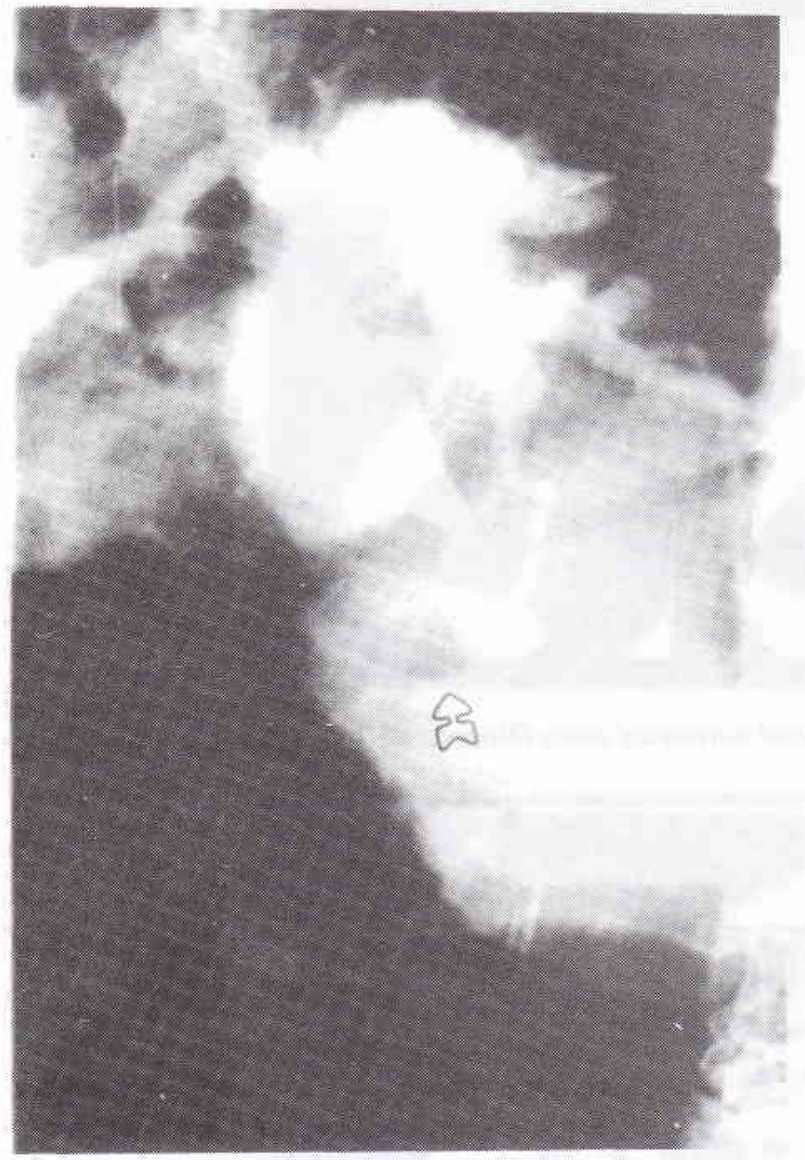

Figure 5. Biliary stenting in an elderly patient with a large $C B D$ stone (arrow) associated with cholangitis

\section{DISCUSSION}

The present study supports the benefit and safety of mechanical lithotripsy in treating difficult CBD stones as previously reported. ${ }^{7,8}$ In contrast to the predominantly cholesterol type of gall-stones found in Western countries, most of CBD stones in our country are belonged to calcium bilirubinate type which are often soft and fragile. ${ }^{18}$ Therefore, ML is highly effective to crush and remove large CBD stones. This might also explain that stone fragmentation and duct clearance could be successfully obtained in one session in these series.

It should be noted that ML with Soehendra lithotryptor was performed only to stones which could be captured in the Olympus Dormia basket. The disadvantage of using Soehendra lithotryptor is the need to reinsert the endoscope in patients with several large stones. The patients with impacted stones in the CBD which could not be captured in the Dormia basket underwent electrohydraulic or pulse dye laser lithotrypsy. Our results have shown that EHL is very effective to fragment impacted stone(s), which are in agreement with earlier studies. ${ }^{8-10}$ One patient in this study, however, developed recurrent stone two years after successful EHL which required surgery. Two recent studies have analysed the risk factors for the formation of recurrent stones after endoscopic sphincterotomy for choledocholithiasis. ${ }^{19,20}$ In the first study, multivariate analysis of 223 patients after sphincterotomy has shown that a bile duct of $15 \mathrm{~mm}$ or greater, and the presence of papillary diverticulum are associated with recurrent $\mathrm{CBD}$ stones. ${ }^{19}$ The second study revealed that recurrent stones occurred in $12.3 \%$ of 410 patients after endoscopic sphincterotomy during a mean follow-up of 122 months. All of these recurrent stones were calcium-bilirubinate type. Since the activity of $\beta$-glucuronidase released from bacteria have been shown to contribute to the formation of calciumbilirubinate stones, this finding suggested the role of ascending biliary infection in the recurrent stone formation. ${ }^{20}$ In fact, our patient with recurrent stone had markedly dilated CBD and the stone was macroscopically calcium-bilirubinate type.

As suggested by others, EHL was carried out under peroral choledochoscopic guidance to avoid complications, since EH shock wave may injure the wall of the bile duct. ${ }^{21,22}$ Our limited experience in two patients with pulse dye laser lithotripsy revealed the effectiveness of this technique in fragmenting impacted stones. The efficacy and safety of laser lithotrypsy appeared to be comparable to EHL when performed under cholangioscopic guidance. ${ }^{14,15}$ Laser lithotripsy might also be useful as an alternative treatment for irretrievable CBD stones in our country, since pigment stones are more susceptible to ablation than cholesterol stones. $^{23}$

Longterm follow-up after ES has shown that about $10 \%$ of patients may develop symptoms including cholangitis, stenosis and recurrent stones. ${ }^{24,25}$ Therefore, careful follow-up of patients is mandatory to investigate late biliary tract complications of ES.

Our results also support previous studies that biliary stenting is an alternative endoscopic method for the treatment of irretrievable CBD stones. ${ }^{16-18}$ The placement of a biliary stent results in immediate biliary drainage, which is essential for treatment and prevention of cholangitis. This may enable elective surgical and endoscopic treatment later, when the condition of the patient is better.

Three of our 5 patients with stent-clogging underwent successful mechanical lithotripsy. These findings indicate that fragmentation and removal of stones should be attempted after biliary stenting at a latter stage. In 
the other two patients which required exchange of stent, the endoprosthesis could serve as a definitive treatment. Long term complications in the other 11 patients with permanent stent were difficult to monitor, since most of them were sent from other centres. In one recent study of 114 patients with irretrievable CBD stones using standard technique, 55 received permanent and 59 temporary stents. ${ }^{26}$ Thirty one of these 59 patients underwent subsequent successful surgery and 25 became stone free after repeating ERC, whereas the remaining three patients received permanent stent. Long term complications occurred in $40 \%$ of those with permanent stent, with cholangitis being the most prevalent. Therefore, it has been suggested that permanent biliary stenting should be restricted to patients who have high risk for elective treatment at a latter stage.

\section{CONCLUSION}

Additional endoscopic procedures including mechanical, electrohydraulic, pulse dye laser lithotripsy and biliary stenting are beneficial in treating difficult CBD stones:

\section{Acknowledgement}

The author wishes to acknowledge the collaboration of Drs. Nanik Tjokrosetio and Aries Bunyamin.

\section{REFERENCES}

1. Classen M, Demling L. Endoscopische sphinckterotomine der papilla Vateri. Deutsch Med Wochenschr 1974; 99: 496-7.

2. Kawai K, Akasaka Y, Murakami M, Tada M, Koli Y. Endoscopic sphincterotomy of the ampulla of Vater. Gastrointest Endosc 1974;20:148-51.

3. Cotton PB. Non-operative removal of bile duct stones by duodenoscopic sphincterotomy. Br J Surg 1980;67:1-5.

4. Viceconte G, Viceconte GW, Pietropaolo V, Montori A. Endoscopic sphingterotomy: indications and results. $\mathrm{Br} \mathrm{J}$ Surg. $1981 ; 68: 376-80$.

5. Mee AS, Vallon AG, Croker JR, Cotton PB. Non-operative removal of bile duct stones by duodenoscopic sphincterotomy in the elderly. Br Med J 1981; 283: 521-3.

6. Schneider MU, Matek W, Bauer R, Domschke W. Mechanical lithotripsy of bile duct stones in 209 patients- effect of technical advances. Endoscopy 1988; 20: 248-53.

7. Siegel J, ben-Zvi JS, Pullano W. Mechanical lithotripsy of common duct stones. Gastrointest Endosc 1990; 36: 351-6.

8. Binmoeller KF, Bruckner M, Thonke F, Soehendra N. Treatment of difficult bile duct stones using mechanical, electrohydraulic and extracorporeal shock wave lithotripsy. Endoscopy 1993; 25: 201-6.

9. Liquory CL, Bonnel D, Canard JM, Cormud F, Dumont JL. Intracorporeal electrohydraulic shock wave lithotripsy of common bile duct stones: preliminary results in 7 cases. Endoscopy 1987: 237-40.

10. Leung JWC, Chung SCC. Electrohydraulic lithotripsy with peroral choledochoscopy. Br Med J 1989; 299: 595-8.

11. Sauerbruch T, Stern M. Fragmentation of bile duct stones by extra-corporeal shock waves. Gastrointerology 1989; 96: 146-52.

12. Staritz M, Rainbow A, Grosse A, Hurst A, Floth A, Mildenberger $P$, et al. Electromagnetically generated extra corporeal shockwaves for fragmentation of extra and intra hepatic bile duct stones: indications, success and problems during a 15 month clinical experience. Gut 1990; 31: 222-5.

13. Ponchon T, Gagnon P, Valette PJ, Henry L, Chavaillon A, Thieulin F. Pulsed dye laser lithotripsy of bile duct stones. Gastroenterology 1991; 100: 1730-6.

14. Dawson SL, Mueller PR, Lee MJ, Saine S, Kelsey P, Nishioka NS. Treatment of bile duct stones by laser lithotripsy: results in 12 patients. AJR 1992; 158: 1007-9.

15. Cotton PB, Forbes A, Leung JWC, Dineen L. Endoscopic stenting for long-term treatment of long bile duct stones: 2-to 5-year follow-up. Gastrointest Endosc 1987; 33: 411-2.

16. Siegel JH, Yatto RP. Biliary endoprosthesis for the management of retained common bile duct stones. Am J Gastroenterol 1984; 79: 50-4.

17. Soomers AJ, Nagengast FM, Yap SH. Endoscopic placement of biliary endoprosthesis in patients with endoscopically unextractable common bile duct stones. A long-term follow-up study of 26 patients. Endoscopy 1990; 22: 24-6.

18. Lesmana LA. Clinical and biochemical aspects of choledocholithiasis [Dissertation]. Amsterdam: University of Amsterdam; 1989.

19. Pereira-Lima JC, Jakobs R, Winter UH, Benz C, Martin WR, Adamek HE, et al. Long-term results ( 7 to 10 years) of endoscopic papillotomy for cholidocholithiasis. Multivariate analysis of prognostic factors for the recurrence of biliary symptoms. Gastrointest Endosc 1998; 48: 457-64.

20. Tanaka M, Tahakata S, Konomi H, Matsunaga H, Yokohata $\mathrm{K}$, Takeda $\mathrm{T}$, et al. Long-term consequence of endoscopic sphincterotomy for bile duct stones. Gastrointest Endosc 1998; 48: 465-9.

21. Horrison J, Morris DL, Haynes J, Hitchlock A, Womack C, Wherry DC. Electrohydraulic lithotripsy of gallstones in invitro and animal studies. Gut 1987; 28: 267-71.

22. Sievert CE, Silvis SE. Evaluation of electrohydraulic lithotripsy on human gallstones. Am J Gastroenterol 1985; 80:854.

23. Nishioka NS, Levins PC, Murray SC, Parrish JA, Anderson RR. Fragmentation of biliary calculi with tunable dye lasers. Gastroenterology 1987; 93: 250-5.

24. Leese T, Neoptolemos JP, Carr-Locke DL. Success, failures, rarely complications and their management following endoscopic spheinecterotomy: results in 394 consecutive patients from a single centre. Br J Surg 1985; 72; 215-9.

25. Escourrou J, Cordova JA, Lazorthes F, Frexinos J. Early and late complications after endoscopic sphincterotomy for biliary lithiasis with and without the gallbladder "in situ". Gut 1984; 25: 598-602.

26. Sergman JJGHM, Rauws EAJ, Tijssen JGP, Tytgat GNJ, Huibregtse K. Biliary endoprosthesis in elderly patients with endoscopically irretrievable common bile duct stones. Gastrointest Endosc 1995; 42: 195-201. 


\title{
Is Widal test still a usefull method as a routine early diagnostic for typhoid fever in hospitals ?
}

\author{
Sylvia Y. Muliawan ${ }^{*}$, Lucky Hartati Moehario ${ }^{\dagger}$
}

\begin{abstract}
Abstrak
Telah dilakukan penelitian uji Widal untuk mengetahui apakah uji Widal sebagai alat diagnostik dini demam tifoid yang rutin dikerjakan di Rumah Sakit masih bermanfaat pada saat ini. Pada penelitian ini digunakan tiga grup spesimen darah tunggal, yaitu 2 grup spesimen berasal dari pasien rawat inap di Rumah Sakit dengan demam yang telah dikonfirmasikan dengan kultur sebagai positif (grup I) dan negatif (grup II), dan satu grup spesimen orang sehat yaitu donor darah. Hasil uji Widal dinyatakan positif bila titer aglutinin $O$ Salmonella typhi lebih dari 80. Pada uji Widal sensitivitas yang diperoleh adalah 37\%, spesifisitas $97 \%$, nilai prediksi positif $90 \%$, dan nilai prediksi negatif $73 \%$. Akhir-akhir ini berkembang berbagai tes serologi, antara lain metode ELISA dengan menggunakan protein membran luar Salmonella typhi sebagai antigen, yang menunjukkan nilai sensitivitas dan spesifisitas lebih tinggi dibanding dengan uji Widal. Dengan demikian, penggunaan uji Widal secara rutin sebagai alat diagnostik dini demam tifoid perlu dipertimbangkan kembali.
\end{abstract}

\begin{abstract}
In this study, we carried out Widal test to establish whether it is still significant as a routine early diagnostic tool of typhoid fever in the present time. We used three groups of patients: the first two groups were hospitalized patients with fever, of which single blood specimen were taken and confirmed by culture as positive (group I) and negative (group II), and the third group was healthy blood donors. Anti $O$ agglutinin titers regarded as positive were those exceeding 1:80. The sensitivity of single Widal test was 37\%, specificity $97 \%$, positive predictive value $91 \%$, and negative predictive value $73 \%$. Other serology tests developed currently, among others the use of outer membrane protein preparation of Salmonella typhi as an antigen in the ELISA test, have shown higher sensitivity and specificity than the Widal test. Therefore, the use of the Widal test as a routine early diagnostic tool for typhoid fever might need to be reconsidered.
\end{abstract}

Keywords: Salmonella typhi, ELISA test, outer membrane protein, anti $O$ agglutinin

Typhoid fever is an endemic acute systemic illness caused by infection of Salmonella typhi (S. typhi). The disease remains a public health problem in developing countries, including Indonesia. In several countries annual epidemiological data for typhoid fever are obtained from clinical or laboratory results, and as the disease mimics several infectious diseases, it is therefore difficult to obtain a true picture of it.

The best method to detect an infection caused by $S$. typhi is by isolation of the microorganism from clinical specimens. ' This method is, however, time consuming, i.e. it usually takes $2-8$ days, ${ }^{2-7}$ and it depends on laboratory facilities available in the areas. Among

\footnotetext{
* Department of Microbiology, Faculty of Medicine, University of Trisakti, Jakarta, Indonesia

+ Department of Microbiology, Faculty of Medicine, University of Indonesia, Jakarta, Indonesia
}

the many methods of obtaining clinical specimens, blood culture is the one routinely used for the isolation of the microorganism. Although culture may show specificity, it lacks sensitivity mainly if the patients have already taken antibiotic treatments. On the other hand, routine serology test, i.e. Widal test, ${ }^{8}$ although widely used, lacks sensitivity and specificity. For a meaningful interpretation of the test, demonstration of a 4-fold rise in antibody titers between acute and convalescent sera in a 7-14 days interval is essential., 3

Due to those reasons, during the last decade efforts have been carried out in developing newer methods for early diagnosis of typhoid fever. One of the diagnostic methods to be developed is ELISA using outer membrane protein (OMP) preparation as an antigen. ${ }^{9-11}$ Previous studies have indicated the suitability of $S$. typhi OMPs as immunogens in stimulating anti-S. typhi antibodies formation. ${ }^{12-14}$ Earlier study conducted by Moehario, et al. $(1997)^{15}$ showed the 


\title{
Six-month follow-up of laser in-situ keratomileusis for myopia
}

Istiantoro, Tjahjono D. Gondhowihardjo, Johan Hutauruk

\begin{abstract}
Abstrak
Penelitian retrospektif untuk menilai hasil refraksi dari laser in-situ keratomileusis (Lasik) menggunakan excimer laser untuk menentukan ketepatan, prediktabilitas, keamanan dan stabilitas koreksi miopia. Lasik dilakukan pada 475 mata pada 302 penderita miopia dengan ekwivalen sferis (ES) dari -0.50 sampai -27 dioptri (D). Dibagi dalam grup $A$ (ES kurang dari $-6.00 D), B(S E-6.00$ sampai -11.99) dan C (ES -12.00 D atau lebih). Pengamatan dilakukan sampai 6 bulan. Hasil: pada semua grup hanya 122 mata mendapat pengamatan 6 bulan. Rerata pra-bedah ES $-8.45 \mathrm{D} \pm 4.66$ dan rerata pra-bedah silinder $-1.10 \mathrm{D} \pm 1.07$ (dari plano sampai $-6.00 \mathrm{D}$ ). Pada 6 bulan, hasil koreksi dalam kisaran $2.00 \mathrm{D}$ dari koreksi seharusnya tercapai pada $95.6 \%$ grup A, $97.7 \%$ grup B dan $78.1 \%$ grup C. Rerata regesi kurang dari $1.00 \mathrm{D}$ terdapat pada semua grup pada pengamatan 6 bulan. Komplikasi terdapat pada 29 mata $(6 \%)$ untuk seluruh grup. Kesimpulan: Lasik sangat efektif dan tepat untuk koreksi miopia rendah dan sedang. Untuk miopia tinggi $(>-12.00 \mathrm{D})$ efektivitas dan prediktabilitas cukup baik. Stabilitas refraksi sampai 6 bulan tampaknya baik, namun diperlukan pengamatan lebih lama lagi.
\end{abstract}

\begin{abstract}
Retrospective study to evaluate the refractive results of laser in-situ keratomileusis (LASIK) using excimer laser performed on myopic eyes; to determine the accuracy, predictability, safety and stability of LASIK as a treatment to correct myopia. LASIK was performed on 475 eyes of 302 consecutive patients with preoperative spherical equivalent refraction (SE) ranging from -0.50 to -27.00 diopters $(D)$. The eyes were assigned to one of three groups: Group A (SE less than $-6.00 \mathrm{D}), \mathrm{B}(\mathrm{SE}-6.00$ to $-11.99 \mathrm{D})$, or C (SE -12.00 $D$ or higher). Follow-up time was up to 6 months. Results: For all groups, follow-up was obtained for 122 eyes at 6 months. The mean preoperative spherical equivalent was $-8.45 \mathrm{D} 4.66$ [SD], and the mean preoperative cylinder was $-1.10 D \pm 1.07$ [SD] (range: plano to -6.00D). At 6 months, $95.6 \%$ of the eyes in Group A, 97.7\% in Group B, and 78.1\% in Group C were within $2.00 \mathrm{D}$ of intended correction. The mean regression at 6 months was less than $1.00 \mathrm{D}$ in all groups. Complications were observed in 29 eyes (6\%) of all groups. Conclusion: LASIK was found to be very effective and predictable in the correction of low and moderate myopia. For high myopia (>-12.00 D), the effectiveness and predictability of LASIK were fairly good. Results after 6 months tend to suggest the stability of postoperative refraction, but long-term follow-up will be required to make further conclusions.
\end{abstract}

Keywords: Lasik, excimer laser, corneal flap technique

The use of ultraviolet 193-nm excimer laser for corneal surgery has been suggested in several studies since the first study by Trokel et al ${ }^{1}$ in 1983 . Radiation emitted by the argon fluoride excimer laser has demonstrated a unique ability to ablate corneal tissue with submicrometer accuracy, leaving minimal residual tissue damage. ${ }^{2,3}$ Its application on human eyes was first published in $1989^{4}$ with a good result. As the technology known as photorefractive keratectomy (PRK) has evolved, there are 2 major problems encountered. The first problem is subepithelial haze in the visual axis,

Department of Ophthalmology, Faculty of Medicine, University of Indonesia, Jakarta, Indonesia and the second is the predictability and stability of the refractive results in high myopia.

Since PRK did not prove its safety, effectiveness, and predictability in myopia higher than $6.00 \mathrm{D} .^{5,6} \mathrm{Pal}-$ likaris et al suggested the corneal flap technique for "laser in situ keratomileusis" (LASIK) for high levels of myopia. LASIK is a refractive surgery technique that uses microkeratome to raise a corneal flap and followed by an excimer laser to ablate the stromal bed. 8,9

This study analyzes the refractive results of 475 consecutive LASIK procedures performed on normal, sighted myopic eyes; to determine its efficacy and predictability as a treatment to correct myopia. 